growth, no abnormalities have been described in brain. Ambient hyperoxia has been reported to inhibit nucleic acid synthesis in mammalian tissue cultures. The present studies suggest that hyperoxia may have similar effects in the developing brain in vivo. Newborn puppies were bottle-raised in $80 \%$ oxygen; weightmatched littermates were raised similarly in air. Over a nine-day period the mean weight gain was the same in both groups. Three days after termination of the oxygen exposure cerebral cortex and white matter were analyzed for DNA and RNA contents. The results obtained in nine pairs of animals were as follows:

Brain nucleic acid $\mathrm{P}_{\mathrm{i}}$ concentration in $\mathrm{mg} \mathrm{P} / 100 \mathrm{~g}$ wet weight, mean \pm S.E.M.

\begin{tabular}{lrrc}
\hline & $\begin{array}{c}\text { Oxygen- } \\
\text { exposed }\end{array}$ & Control & $\begin{array}{c}\mathrm{p} \\
\text { value }\end{array}$ \\
\hline DNA, gray matter & $6.84 \pm 0.53$ & $7.48 \pm 0.57$ & $<0.01$ \\
RNA, gray matter & $11.82 \pm 0.66$ & $13.07 \pm 0.72$ & $<0.02$ \\
DNA, white matter & $6.35 \pm 0.30$ & $6.84 \pm 0.38$ & n.s. \\
RNA, white matter & $8.94 \pm 0.31$ & $9.88 \pm 0.42$ & $<0.02$ \\
\hline
\end{tabular}

No differences were found in histologic examinations of brain sections. These findings indicate that ambient hyperoxia may inhibit nucleic acid snythesis and cell proliferation in the developing dog brain.

Subacute Sclerosing Panencephalitis: $A$ New Serological Test in the Diagnosis of the Disease. MichaEL Katz, Volker ter Meulen, Larry Leonard and Hrlary Koprowskr, Nistar Inst., Philadelphia, Pa., Dept. of Ped., Univ. of Göttingen, Germany, and California Dept. of Public Health, Berkely, GA.

In patients suspected of subacute sclerosing panencephalitis (SSPE) high levels of measles antibody in the serum and CSF have been taken as a supporting diagnostic criterion for the disease. In the present study 14 sera from patients with SSPE, 3 early-measles-convalescent sera and 100 late-measles-convalescent sera were used for indirect immunofluorescent examination of tissue culture cells infected with wild measles virus and SSPE viruses. All 14 SSPE sera reacted with an antigen in the nuclei and cytoplasm of these infected cells, as did the 3 convalescent sera obtained 3 weeks after the onset of measles. However, no intranuclear fluorescence was detected when the 100 sera obtained
5 months or later after measles infection were used. Thus, SSPE sera derived from patients who had measles many months, or years, prior to the onset of their neurological disorder, behaved like early convalescent sera. This unusual characteristic can be applied as a diagnostic test for SSPE. (Supported by USPHS grant NS-6859; Grant MS 596-A-2 from the Nat. Multiple Sclerosis Soc.; DG grants Me270/4 and 270/6; and USPHS grant AI-1475.)

182 Characteristics of Measles Virus Isolated from $\mathrm{Pa}$ tients with SSPE. JOSEPH V. BAUBLIS and FRANCIS E.PAyne, Univ. of Michigan Sch. of Med., Dept. of Ped., and Sch. of Pub. Health, Dept. of Epid., Ann Arbor, MI (introduced by A.V. Hennessy).

We have isolated measles virus from brain cell cultures derived from two children less than one year following immunization with a live virus vaccine. Recovery of 'mature' measles virus was accomplished only after prolonged serial subcultivation of cells from the patients, or cells from the patient cultured together with BS-C-1 cells or primary human kidney cells. Cell cultures before the 12th level of subcultivation showed the cytopathology and antigen associated with measles infection but produced no free virus. Isolation of measles virus from earlier passage levels of these cells was accomplished by intracerebral inoculation of newborn hamsters. Characterization studies completed to date have shown that the isolates are antigenically indistinguishable from other strains of measles virus. However, they have a distinctive CPE characterized by extensive syncytial formation and produce very large plaques under agar overlay. In continuous lines of monkey kidney cells they yield a low titer of virus, but grow poorly or not at all in continuous human cell lines. They are distinguishable from other strains of measles by their resistance to thermal inactivation at $40^{\circ} \mathrm{C}$. Both strains produce fatal, acute encephalitis in baby hamsters. The lack of information regarding viral markers and their stability for vaccine and wild strains of measles, has made it impossible to determine the origin of the isolates on the basis of laboratory studies. This situation stresses the need for continuing emphasis on epidemiologic surveillance of SSPE, as well as laboratory research on measles virus and its markers.

\title{
INDEX OF ABSTRACTS
}

(Numbers following entries refer to abstract number)

AbildgaARd, C.F. 115

absorption, jejunal 164 ACETO, T., Jr. 94

acid-base homeostasis 46 acid mucopolysaccharide 21 acidosis 135

acidosis, metabolic 64

ACTH 93

Adams, M.S. 151

adenine nucleotide 116

$S$-adenosyl-L-methionine 75

adipose tissue 70

adrenal 87

adrenal, $\alpha$-inhibition 84

adrenal, function 91, 93 adrenal hyperplasia, congenital 89 adrenal hyperplasia, lipoid 77 adrenocorticosteroid 103 airway obstruction 168

Aksu, A. 175

alanine 64

alcoholism, maternal 152

aldosterone 80, 85

alkaline phosphatase 60

allergy 2

alpha $_{1}$-antitrypsin 165

AL-UBAIDI, Y.Y. 49

amino acid metabolism 47, 71 aminoaciduria 175 aminoglutethimide 77

Ammann, A.J. 3

ammonia 44,45

amniocentesis 20

Ances, I. G. 80

androgens 128

anemia, aplastic 130

anesthesia 139

ANTHONY, B. F. 95

Anthony, C.L., Jr. 147

antibiotics 144

antibodies $3,4,6$

antibody 101, 102

antielastase 165

antistaphylococcus 111 